\title{
The regulation of expression of the porin gene ompC by acid $\mathrm{pH}$
}

\author{
Alison D. ThOMas and IAN R. BOOTH* \\ Department of Molecular and Cell Biology, University of Aberdeen, Marischal College, Aberdeen AB9 IAS, UK
}

(Received 30 March 1992; revised 5 June 1992; accepted 16 June 1992)

\begin{abstract}
The regulation of expression of the porin genes of Escherichia coli by acid pH was investigated using reporter gene fusions. The ompC-lac $Z$ gene fusion was expressed in response to acidification of the external medium. The kinetics of $\beta$-galactosidase synthesis under acid-induction differed significantly from those obtained under conditions of osmotic stress. The latter led to rapid induction without a lag, followed by establishment of a rate that was equal to the growth rate; acid-induction was frequently preceded by a short lag period, was relatively slow and did not achieve a rate that was in balance with the growth rate. Further, induction of the omp $C$ gene at acid external pH was dependent upon the presence of glucose as sole carbon source; growth with either glycerol or succinate as sole carbon source reduced induction of ompC at acid $\mathrm{pH}$. Osmotic induction was independent of carbon source. The induction of the ompC gene at acid $\mathrm{pH}$ was also reduced by addition of $\mathrm{cAMP}$ to the growth medium. The porins are known to be subject to catabolite repression and our data are consistent with the exposure to acidic pH resulting in progressive changes in the state of catabolite repression. Acidification of the cytoplasm also provoked a rapid induction of the $o m p C$-lac $Z$ gene fusion. The kinetics of induction resembled the response to osmotic upshock. This response was independent of the identity of the carbon source supplied for growth. The contribution of changes in cytoplasmic $\mathrm{pH}$ to the induction of ompC at acid $\mathrm{pH}$ is discussed.
\end{abstract}

\section{Introduction}

The mechanisms that allow bacterial cells to respond to environmental stresses have been the subject of intense enquiry in the last 10 years. There are two primary routes now recognized by which environmental stress is signalled leading to changes in gene expression that increase the ability of the cell to survive. The major mechanism for the detection of external stimuli is the two component histidine kinase/response regulator family of proteins (Stock et al., 1989). One component, which is frequently a transmembrane protein, senses the change in the environment and transmits a conformational change that affects the activity of the protein-histidine kinase domain located at the cytoplasmic face of the membrane. Autophosphorylation of the kinase domain at the expense of ATP is followed by transfer of the phosphate group to the response regulator protein. Many of the response regulators are DNA-binding proteins. One example of such a system is the EnvZ/OmpR system that regulates the expression of the genes for the outermembrane porins OmpF and OmpC (Mizuno \& Mizushima, 1990).

* Author for correspondence. Tel. (0224) 273152; fax (0224) 273144.
In Escherichia coli the expression of the porins $\mathrm{OmpF}$ and $\mathrm{OmpC}$ is regulated by many environmental stimuli including osmotic pressure, temperature and $\mathrm{pH}$. [In addition, it has been observed that the porin genes are also subject to catabolite repression; carbon sources that exert strong catabolite repression lead to expression of the ompC locus (Scott \& Harwood, 1980).] High osmotic pressure, high temperature and acidification of the growth medium result in a switch from the expression of the OmpF porin to the OmpC porin (Mizuno \& Mizushima, 1990; Heyde \& Portalier, 1987). This switch has been proposed to arise primarily from changes in the cellular level of the phosphorylated form of OmpR (Mizuno \& Mizushima, 1990). High levels of OmpR-P favour the expression of OmpC porin. The OmpR-P phosphatase component of the EnvZ protein has recently been shown to be inactivated by high cytoplasmic concentrations of potassium glutamate elicited by changes in external osmotic pressure (Tokishita et al., 1990).

The second major mechanism by which environmental changes effect adaptation is the environmentally controlled change in DNA supercoiling (Drlica et al., 1990; Higgins et al., 1990; Hsieh et al., 1991). It has been shown that changes in growth rate, osmotic pressure, 
temperature and anaerobiosis cause changes in the degree of negative supercoiling of the DNA leading to adaptive changes in gene expression (Higgins et al.,1988; Dorman et al., 1988; Graeme-Cook et al., 1989). Increases in negative supercoiling of the DNA are observed in cells that are adjusting to high osmotic pressure and to anaerobiosis (Dorman et al., 1988; Graeme-Cook et al., 1989). Anaerobiosis elicits OmpRindependent expression of the ompC locus (GraemeCook et al., 1989). It has been proposed that changes in DNA supercoiling, elicited by higher osmotic pressure and by anaerobiosis, are synergistic with the changes in OmpR-P in eliciting $o m p C$ expression (Graeme-Cook et al., 1989). The precise mechanism by which environmental stimuli influence the degree of negative supercoiling has yet to be determined. However, it is likely that changes in the concentration of molecules in the cytoplasm are the intermediary effectors.

Recently, the ability of bacteria to adapt to acidic $\mathrm{pH}$ has been stressed as a potential problem in the design of food preservation regimes (Brown \& Booth, 1991). The present study was undertaken to analyse the changes in porin gene expression during growth at acid $\mathrm{pH}$ (Heyde \& Portalier, 1987) and to understand how changes in external $\mathrm{pH}$ might elicit changes in gene expression. The data point to significant differences between the sensing of external $\mathrm{pH}$ and of cytoplasmic $\mathrm{pH}$. From the data we infer that external $\mathrm{pH}$ may influence porin gene expression due to $\mathrm{pH}$-elicited changes in the cytoplasmic level of cAMP. The mechanism by which cytoplasmic acidification elicits the change in ompC expression is discussed.

\section{Methods}

Bacterial strains. Escherichia coli $\mathbf{K} 12$ strains were used throughout:

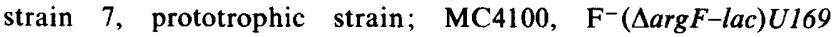
araD139 rpsL150 relA1 ptsF25 deoC1 thiA flbB5301 rbsR; MH225, derived from MC4100 (ompC-lac $Z^{+}$)10-25[p1(209)]; MH513, derived from MC4100 (ompF-lacZ+)16-23[p1(209)]; GM37, derived from MC4100 (proV-lacZ)(Hyb2)(גplacMu15). MH225, MH513 and GM37 were obtained from Professor C. F. Higgins, ICRF Laboratories, Institute for Molecular Medicine, University of Oxford, UK.

Growth medium. Medium S (Ahmed \& Booth, 1981) was used throughout. The medium was adjusted to $\mathrm{pH} 6.0$ or $\mathrm{pH} 7.8$ by mixing appropriate volumes of the phosphate buffer. At $\mathrm{pH} \mathrm{6.0} \mathrm{NaCl}$ was added to compensate for the change in medium osmolarity caused by the different balance of the potassium and phosphate ions.

Growth and $\beta$-galactosidase assay. Growth was monitored by measuring the optical density (OD) at $600 \mathrm{~nm}$ in an LKB spectrophotometer. Overnight cultures were diluted into fresh growth medium at the same $\mathrm{pH}$ and grown to mid-exponential phase prior to dilution in the test incubation and analysis of gene expression. Weak acids were added from 100 -fold concentrated sterile stock solutions pre-adjusted to $\mathrm{pH} 6 \cdot 0 . \mathrm{NaCl}$ and glucose were used to raise the osmotic pressure and were added from sterile stock solutions. $\beta$-Galactosidase was measured by the method of Miller (1972) using $50 \mu \mathrm{l} 0 \cdot 1 \%$ (w/v) SDS and $100 \mu \mathrm{l}$ chloroform to permeabilize the $100 \mu$ l of cells diluted with $900 \mu \mathrm{l}$ of $\mathrm{Z}$ buffer (Miller, 1972). Controls were conducted with different volumes of cells, SDS and chloroform and no significant deleterious effects were observed with the permeabilization conditions used. The data are presented in the form of units of $\beta$-galactosidase per $\mathrm{OD}_{600}$ unit as defined by Miller (1972).

Measurement of cytoplasmic $p H$. The measurements of cytoplasmic pH were made using $\left[7^{-14} \mathrm{C}\right]$ benzoic acid $[2 \mu \mathrm{M}$ final concentration; $24 \cdot 4$ $\mu \mathrm{Ci} \mu \mathrm{mol}^{-1}\left(903 \mathrm{GBq} \mathrm{mol}^{-1}\right.$ ] and ${ }^{3} \mathrm{H}_{2} \mathrm{O}$ [approx. $1 \mu \mathrm{Ci} \mathrm{ml}{ }^{-1}(37 \mathrm{kBq}$ $\mathrm{ml}^{-1}$ )] using a centrifugation-based assay (Ahmed \& Booth, 1981).

Reagents. All reagents were purchased from Sigma; growth media were from BDH and from Oxoid.

\section{Results}

\section{$p H$-regulated expression of the ompC and ompF loci}

It has been demonstrated previously that the expression of the porin genes is affected by the $\mathrm{pH}$ of the growth medium (Heyde \& Portalier, 1987; Heyde et al., 1988). When cultures of the $E$. coli strains MH225 (ompC-lacZ) and MH513 (ompF-lacZ) were grown at constant osmolarity at either $\mathrm{pH} 7.8$ or $\mathrm{pH} 6$ a reciprocal relationship in the $\beta$-galactosidase of the cultures was observed (Fig. 1). With strain MH225, $\beta$-galactosidase activity increased in cultures grown at acid $\mathrm{pH}$ and was essentially constant in cells grown at $\mathrm{pH} 7.8$, while the opposite was observed for strain MH513. The $\mathrm{pH}$ dependent change in gene expression did not take place immediately on initiation of growth at the new $\mathrm{pH}$. Dilution of cells to an $\mathrm{OD}_{600}$ of 0.05 was followed by rapid growth at a rate that was independent of the external pH. Only when the cells had accomplished several generations at $\mathrm{pH} 6$ was a change in the expression of the $\operatorname{ompC}$ locus noted. The synthesis of $\beta$ galactosidase took place at a rate faster than that of growth and the rate of synthesis did not diminish even when the cells were diluted in mid-exponential phase and grown in fresh growth medium (Fig. 1).

The pattern of gene expression differed from that observed when cells were subjected to an osmotic upshock (Fig. 2). The addition of $0 \cdot 2 \mathrm{M}-\mathrm{NaCl}$ increased $\beta$-galactosidase levels rapidly as expected for expression of the $o m p C$ gene and osmotic induction was not affected by the $\mathrm{pH}$ of the growth medium (Fig.2). However, osmotic induction was considerably faster than acidinduction of $o m p C$ (Fig. 2). After three generations at the higher osmolarity, the rate of synthesis of $\beta$-galactosidase slowed to parallel the rate of increase in biomass (Fig. 2). When these cells were diluted into fresh growth medium at the same osmolarity and $\mathrm{pH}$ constant levels of $\beta$ galactosidase were observed, indicating complete adaptation to the new growth environment (Fig. 2). In contrast, cells in which the $o m p C$ gene was induced by 

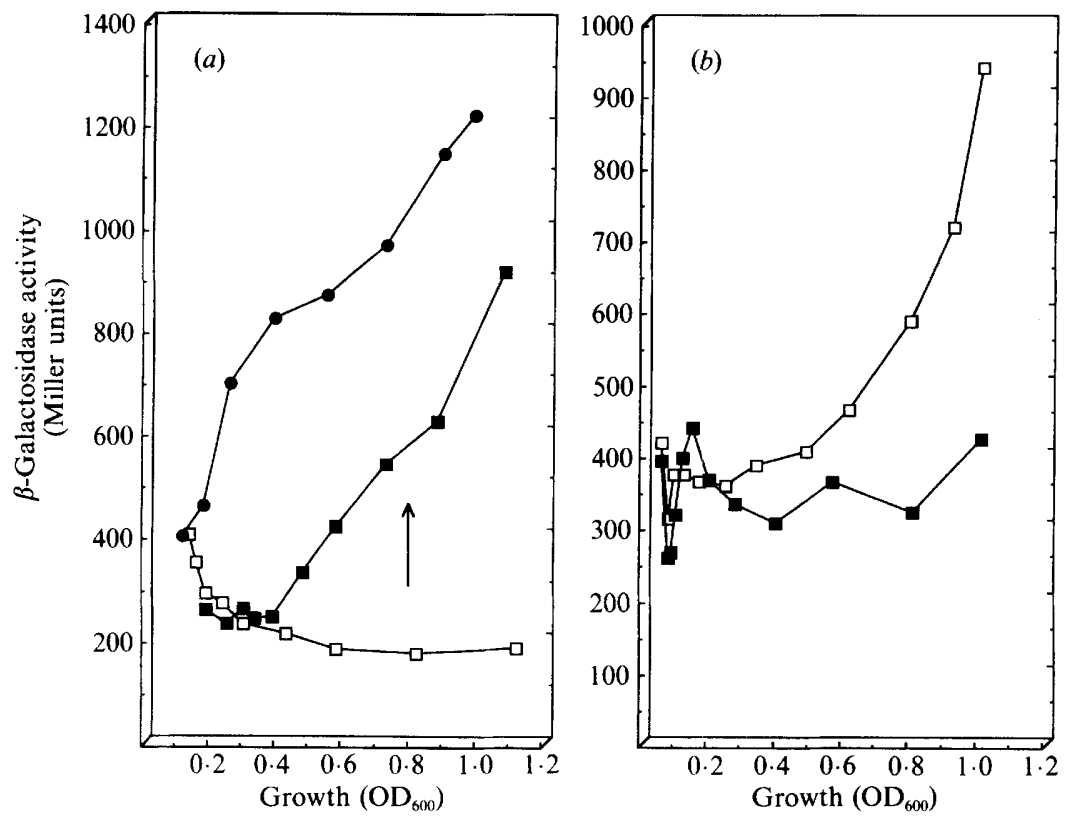

Fig. 1. Effect of $\mathrm{pH}$ on the expression of OmpC and OmpF. Overnight cultures of (a) strain MH225 (ompC-lacZ) and (b) strain MH513 (ompF-lacZ), grown at $\mathrm{pH} 7.8$ and $\mathrm{pH} 6.0$, respectively, were diluted into fresh growth medium at either $\mathrm{pH} 6.0$ (filled symbols) or $\mathrm{pH} 7.8$ (open symbols) to give an $\mathrm{OD}_{600}$ of 0.05 . The new cultures were incubated at $37^{\circ} \mathrm{C}$ in a shaking incubator and samples removed at intervals and analysed for growth $\left(\mathrm{OD}_{600}\right)$ and $\beta$ galactosidase activity. After four generations growth at $\mathrm{pH} 6$ (arrow) the strain MH225 culture was diluted into fresh growth medium $(\mathcal{O})$ and the incubation and analysis continued.

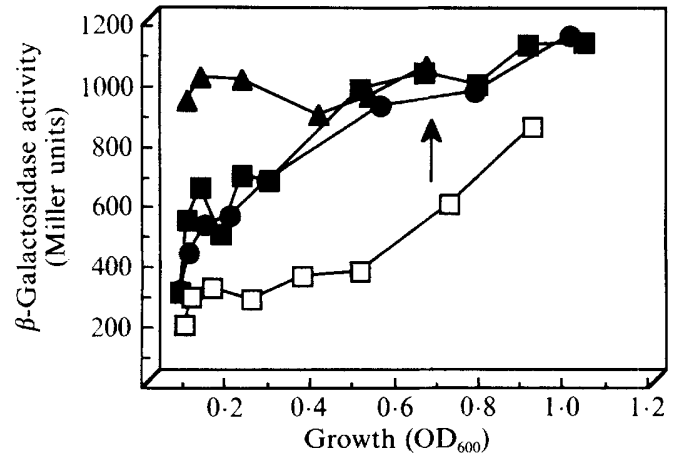

Fig. 2. Osmotic induction of the $o m p C$ gene by osmotic upshock. An overnight culture of strain $\mathrm{MH} 225$ was grown to mid-exponential phase at $\mathrm{pH} 7.8$ and then diluted into fresh growth medium at either $\mathrm{pH} 6$ with (O) or without $(\square)$ addition of $0.2 \mathrm{M}-\mathrm{NaCl}$ to induce the $o m p C$ gene, or medium at $\mathrm{pH} 7.8$ containing $0.2 \mathrm{M}-\mathrm{NaCl}(\square)$. Once the culture grown at $\mathrm{pH} 6$ with $0 \cdot 2 \mathrm{M}-\mathrm{NaCl}$ had reached $\mathrm{OD}_{600}=0 \cdot 7$ the culture was diluted to $\mathrm{OD}_{600}=0.05$ with pre-warmed medium of the same composition (arrow) and sampling continued $(\boldsymbol{A})$. The analysis of growth and $\beta$-galactosidase activity was conducted as described for Fig. 1.

acid $\mathrm{pH}$ alone did not appear to adapt in that the rate of $\beta$-galactosidase expression did not diminish even after dilution into fresh growth medium at the same pH (Fig. $1 a$ ). This suggests that there may be physiologically distinct mechanisms controlling the level of expression of the $o m p C$ gene under the two different environmental conditions.
Influence of carbon source on pH-regulated changes in gene expression

Growth rate is lowered by an increase in the osmolarity of the growth medium. In order to control for this variable, we varied the carbon source to slow the growth rate of strains MH513 and MH225 and monitored the effect on $\beta$-galactosidase at $\mathrm{pH} 6$. Growth of cells of strain $\mathrm{MH} 225(\mathrm{ompC}-\mathrm{lacZ})$ at $\mathrm{pH} 6$ with either glycerol or succinate as sole carbon source lowered the growth rate as expected, but suppressed the synthesis of $\beta$ galactosidase compared with growth on glucose. With succinate, there was no significant change in $\beta$ galactosidase expression over several generations, while with glycerol the rate of synthesis of $\beta$-galactosidase was reduced compared with glucose (Fig. 3). In the parallel experiment, expression of the ompF gene in strain MH513 was increased by substitution of glycerol for glucose as carbon source (Fig. 3). Thus, the pHdependence of porin expression is only evident when glucose is the sole carbon source.

This pattern implied that catabolite repression might be involved in the $\mathrm{pH}$-dependent expression of the porins since the CAP (catabolite activator protein)-cAMP system has been shown to alter the regulation of porin synthesis (Scott \& Harwood, 1980). The effect of cAMP (1 mM final concentration) addition to glucose-grown cultures of strains MH513 and MH225 at pH 6 was investigated (Fig. 4). It was clear that addition of cAMP reduced the synthesis of $\beta$-galactosidase from the $o m p C$ promoter. However, despite the obvious response of cells 


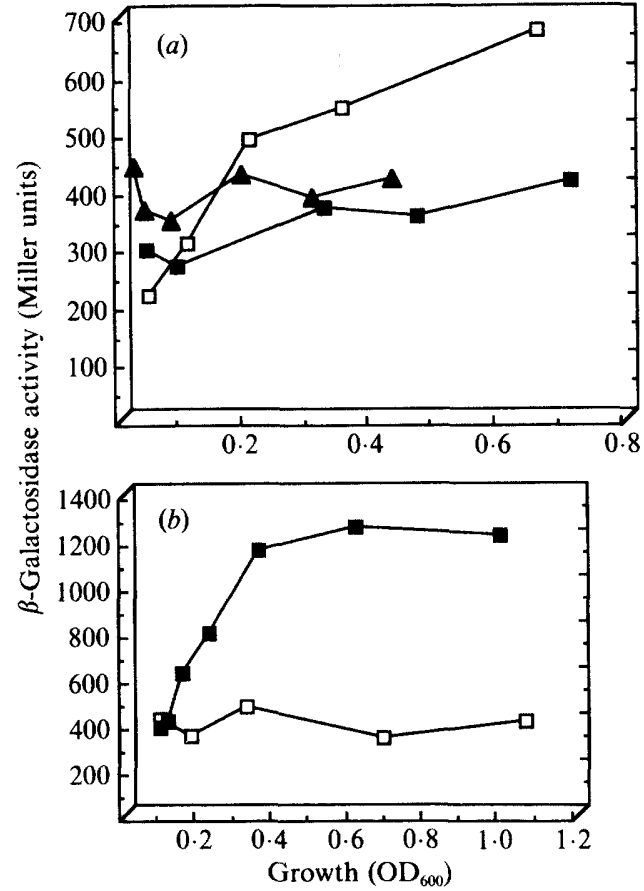

Fig. 3. Effect of carbon source on porin gene expression. Cultures of strains MH225 (a) and MH513 (b) were grown at pH 6 with glucose $(\square)$, glycerol $(\boldsymbol{D})$ or succinate $(\boldsymbol{A})$ as sole carbon source and the growth and $\beta$-galactosidase expression analysed as in Fig. 1.

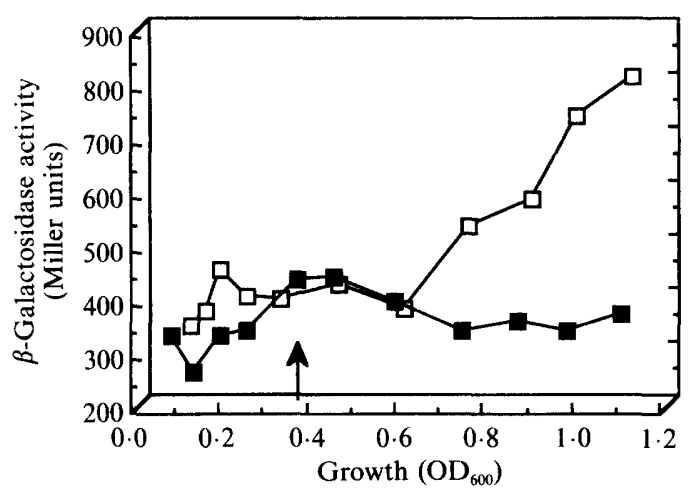

Fig. 4. Effect of cAMP on OmpC expression at pH 6. An overnight culture of strain $\mathrm{MH} 225$ was diluted into fresh growth medium at pH 7.8 and grown to mid-exponential phase. The culture was then diluted into fresh growth medium at $\mathrm{pH} 6$ and growth continued. After three generations growth, CAMP ( $1 \mathrm{mM}$ final concentration) was added to one culture (arrow) and the incubation continued. Growth and $\beta$ galactosidase were analysed as in Fig. 1 . The growth rate of the culture was unaffected by the presence of cAMP. $\square$, No cAMP; $\square, 1 \mathrm{mM}$ cAMP.

of MH513 to the change of carbon source from glucose to glycerol (Fig. 3) we were unable to see any stimulation of ompF-lac $Z$ expression in parallel incubations of cells with glucose and cAMP at pH 6 (data not shown). The rapid induction of $o m p C$ expression in response to an osmotic upshock was independent of the carbon source in the growth medium (data not shown). In conclusion, most of the data point to the $\mathrm{pH}$-dependent change in porin expression arising as a consequence of subtle changes in the state of catabolite repression in cells growing at $\mathrm{pH} 6$.

\section{Cytoplasmic acidification leads to increased expression of ompC}

Whilst seeking for the mechanism by which cells sense changes in external $\mathrm{pH}$, we investigated the effect of changes in cytoplasmic $\mathrm{pH}$ on $o m p C$ expression. The cytoplasmic pH of $E$. coli cells varies by approximately $0 \cdot 1 \mathrm{pH}$ unit per $\mathrm{pH}$ unit change in the environmental $\mathrm{pH}$ (Ahmed \& Booth, 1981). Further, glucose metabolism leads to the production of acetate during growth, which at low $\mathrm{pH}$ could lead to a reduction of cytoplasmic $\mathrm{pH}$ as growth proceeds and acetate accumulates in the medium. Whether changes in cytoplasmic $\mathrm{pH}$ could result in alterations in gene expression was investigated by the addition of two weak acids, acetic acid and benzoic acid, to the growth medium. Cells of strain MH225 were grown at pH 6 in the presence of either sodium acetate or sodium benzoate at concentrations sufficient to cause $40 \%$ inhibition of the growth rate (maximum concentration $8 \mathrm{~mm}$-acetate $-\mu=0.44 \mathrm{~h}^{-1} ; 1.5 \mathrm{~mm}$-benzoate $\mu=0.48 \mathrm{~h}^{-1}$; control $\mu=0.74 \mathrm{~h}^{-1}$ ). Cultures grown in the presence of the weak acids achieved steady state internal $\mathrm{pH}\left(\mathrm{pH}_{\mathrm{i}}\right)$ values between $\mathrm{pH}_{\mathrm{i}} 7 \cdot 6 \pm 0 \cdot 2$ (no acetic or benzoic acid) and $\mathrm{pH}_{\mathrm{i}} 6.9 \pm 0.2(8 \mathrm{~mm}$-acetic acid or $1.5 \mathrm{~mm}$-benzoic acid). Acidification of the cytoplasm provoked a rapid increase in the expression of the $o m p C$ locus. The rate of expression of $\beta$-galactosidase increased as the internal $\mathrm{pH}$ was lowered by the addition of higher concentrations of the weak acid (Fig. 5). In contrast to the effect of external acidification alone (Fig. $1 a$ ), with the highest concentration of weak acid tested, $\beta$-galactosidase activity increased rapidly but then achieved a balance with growth approximately three generations after the addition of a permeant acid (Fig. 5). The highest concentrations of weak acid investigated elicited a change in expression similar to that seen with an osmotic upshock, whilst lower concentrations gave a slower response that was still faster than that seen without addition of the weak acid. The increase in $o m p C$ expression elicited by addition of acetate and benzoate was not dependent upon the nature of the carbon source for growth; substitution of glycerol for glucose did not prevent induction of the ompC locus by acetate or benzoate. Thus, the data point to the ability of the cell to sense quite small changes in cytoplasmic $\mathrm{pH}$ and also show that such small changes can be sufficient to effect changes in gene expression. 


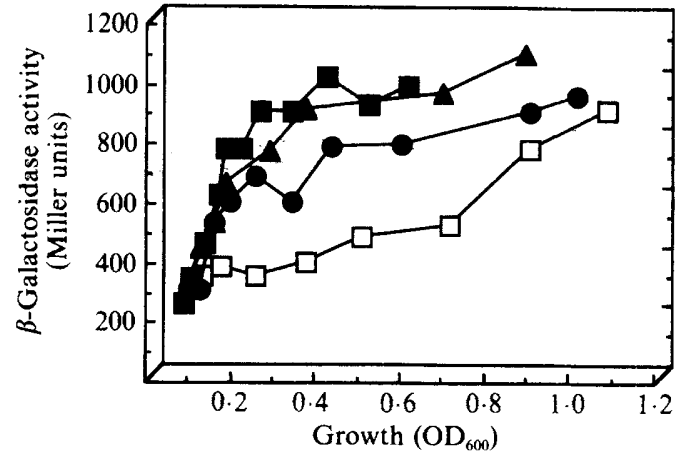

Fig. 5. Acid induction of the OmpC locus. A culture of strain MH225 was grown to mid-exponential phase at $\mathrm{pH} 7.8$ and then diluted into fresh growth medium containing different concentrations of sodium acetate or sodium benzoate at pH 6: $\square$, No added acetate;, $4 \mathrm{~mm}$ sodium acetate; $\boldsymbol{\square}, 8 \mathrm{~mm}$-sodium acetate; $\Delta, 1.5 \mathrm{~mm}$-sodium benzoate. Data obtained with $2 \mathrm{~mm}$-acetate were intermediate between the control incubation and that with $4 \mathrm{~mm}$-sodium acetate and have been omitted for the sake of clarity. Analysis as in Fig. 1.

\section{Expression of the proU locus at acid pH}

The sensitivity of the $o m p C$ locus to a variety of stresses lead us to investigate the response of the proU locus to $\mathrm{pH}$ stress. The regulation of this locus by osmotic stress is still the subject of controversy; however, most workers agree that an increase in DNA supercoiling is required to effect gene expression and that potassium glutamate may affect the promoter specificity of RNA polymerase (Higgins et al., 1988; Prince \& Villarejo, 1989). Expression of pro $U-l a c Z$ was monitored at a moderate osmotic pressure (medium S plus $0.2 \mathrm{M}-\mathrm{NaCl}$ ) to give intermediate levels of proU expression (Cairney et al., 1985), which would allow the detection of $\mathrm{pH}$-induced increases or decreases in proU expression. Growth of strain GM37 (proU-lacZ) at pH 6 in the presence of $0.2 \mathrm{M}-\mathrm{NaCl}$ depressed the synthesis of $\beta$-galactosidase compared with similar cultures grown at $\mathrm{pH} 7.8$ (Fig. 6). A further reduction in the expression of the locus occurred when benzoic acid (1.5 mM) was added to the growth medium at $\mathrm{pH} 6$ (Fig. 6). The effect of acid conditions appeared to be primarily on the steady state level of expression of the locus since the differential rate of synthesis of $\beta$ galactosidase was similar in all three incubation conditions. Changes in proU in response to osmotic upshock are believed to be consequent upon the accumulation of potassium glutamate (Sutherland, et al., 1988; Booth \& Higgins, 1990). Thus, parallel measurements of potassium accumulation under the different growth conditions were undertaken; these studies revealed no significant differences that might account for changes in proU expression (data not shown).

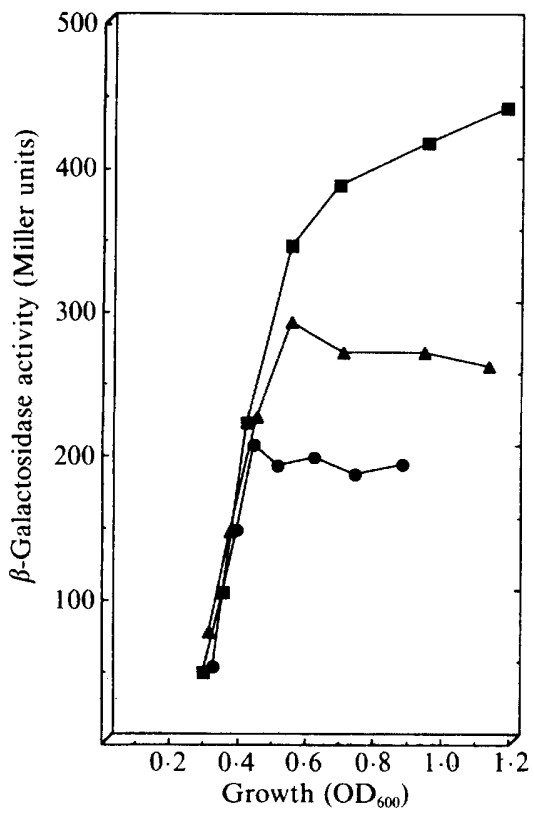

Fig. 6. Effect of pH on expression of the proU locus. Cultures of strain GM37 (proU-lacZ) were grown in low osmolarity media to midexponential phase and then diluted into media containing $0.2 \mathrm{M}-\mathrm{NaCl}$. Growth and $\beta$-galactosidase were analysed as before. Incubation

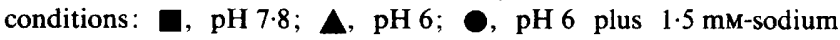
benzoate.

\section{Discussion}

Our studies relate only to the expression of the three loci $o m p F, o m p C$ and $p r o U$ as a consequence of changes in the external and cytoplasmic pH. It has been established previously that the $o m p C$ locus is induced by growth of cells at acidic pH values (Heyde \& Portalier, 1987; Heyde et al., 1988). In the present study, we have shown that the $\mathrm{pH}$-induced expression of the $\operatorname{ompC}$ locus is dependent upon the carbon source in the growth medium, that there are qualitative differences in the activation of $o m p C$ by osmotic pressure and external $\mathrm{pH}$ and that the ompC locus also responds to acidification of the cytoplasm. In this instance the response is very similar to that observed when the osmotic pressure is raised.

The change in porin gene expression mediated by external $\mathrm{pH}$ was only seen when glucose was the carbon source, although earlier workers also noted this change in cells growing on complex media (Heyde \& Portalier, 1987; Heyde et al., 1988). From the time-course of the change in gene expression it is clear that the $\mathrm{pH}$ dependent expression of the porins is a very subtle effect requiring several generations at the low $\mathrm{pH}$ before it is manifested. This may indicate that it is the accumulation of a signal or the removal of an inhibitor that is sensed. 
The levels of cAMP have been reported to affect porin synthesis, high cAMP levels suppressing ompC expression and vice versa (Scott \& Harwood, 1980; C. Harwood, personal communication). This is consistent with our data; glucose, a carbon source associated with low cAMP and thus with strong catabolite repression, was required for $o m p C$ expression at acid $\mathrm{pH}$. Addition of cAMP partially reversed the induction of $o m p C$ at acid $\mathrm{pH}$. Similarly, use of glycerol or succinate as sole carbon source at $\mathrm{pH} 6$ resulted in expression of $o m p F$ rather than $o m p C$. Thus, the expression of the $o m p C$ locus by changes in the external $\mathrm{pH}$ may be an indication of subtle changes in the state of catabolite repression in the cells.

The regulation of the porin genes by cAMP is complex; Scott \& Harwood (1980) noted that deletions of the $c r p$ or $c y a$ genes resulted in constitutive synthesis of the ompC locus; we have confirmed this observation and found that $\mathrm{pH}$ had no effect in such mutants. More recently, it has been shown that the expression of the OmpR/EnvZ couple is also modulated by cAMP (Huang et al., 1992). It is well established that there is a hierarchy of responses to the cAMP-CAP complex (de Crombrugghe et al., 1984) and it can be readily envisaged that growth with glucose at acid $\mathrm{pH}$ may reduce cAMP levels sufficiently to elicit the change in porin gene expression. It has been reported that growth of $c r p$ and cya mutants of $E$. coli is more restricted at alkaline $\mathrm{pH}$ than at acid $\mathrm{pH}$ (Ahmad \& Newman, 1988), suggesting that growth under the latter condition might be one in which cAMP is normally low in wild-type cells.

The effect of cytoplasmic acidification on ompC is very similar to that observed with an increase in osmolarity. This effect was independent of the carbon source used for growth and, therefore, may be completely independent of the catabolite repression phenomena described above. Recently, the activation of $o m p C$ expression by high osmolarity has been explained in terms of the inhibition of the phosphatase activity of the EnvZ protein by high intracellular potassium concentrations (Tokishita et al., 1991). If one assumes that this reflects the distortion of the protein conformation by high salt (Booth \& Higgins, 1990), then it is a reasonable speculation that the same protein element may be similarly susceptible to changes in cytoplasmic $\mathrm{pH}$. We favour the effect of $\mathrm{pH}$ on the enzyme activity rather than the accumulation of a potentially chaotropic anion because the two weak acids exert their effects at different concentrations (and therefore different cytoplasmic concentrations) while they change cytoplasmic $\mathrm{pH}$ to a similar extent. Thus, we suggest that the effects of acetate and benzoate on ompC expression could be explained through a $\mathrm{pH}$-dependent change in the activity of the EnvZ phosphatase activity leading to accumulation of OmpR-P. Clearly, this mechanism could also contribute to the induction of $o m p C$ during growth at acid $\mathrm{pH}$. However, induction of $o m p C$ continues at acid $\mathrm{pH}$ when the cells are diluted into fresh growth media in which the concentration of glucose-derived acetate will be very low. In consequence acetate-provoked acidification of the cytoplasm should not be a component of the induction of $o m p C$ at acid $\mathrm{pH}$.

Both the external $\mathrm{pH}$ and the cytoplasmic $\mathrm{pH}$ were found to affect the induction of the proU locus by osmotic pressure. It is generally held that the induction of the proU locus results from changes in DNA topology (Higgins et al., 1988) and/or in the activity of RNA polymerase (Prince \& Villarejo, 1990). Each research group in this active area holds different views on the relative importance of these two potential mechanisms. However, there is now strong evidence for environmental modulation of DNA topology through changes in supercoiling and there is evidence for the expression of some genes being differentially sensitive to the state of supercoiling of the DNA (Higgins et al., 1988, 1990; Graeme-Cook et al., 1989; Drlica et al., 1990; Ni Bhriain et al., 1989). The effect of $\mathrm{pH}$ on proU would be consistent with reduced DNA supercoiling under acid conditions, although it is not possible at this stage to rule out other explanations.

In conclusion, we have shown that the response of the ompC locus to acidification of the medium is quantitatively and qualitatively different to that during the response to increased osmotic pressure. Perhaps most importantly, the response to acid external $\mathrm{pH}$ is conditional upon glucose as a carbon source and would appear to be a subtle manifestation of changes in the state of catabolite repression in the organism. However, the cell responds to changes in cytoplasmic $\mathrm{pH}$ in a way analogous to the response to osmotic upshock, i.e. there is a rapid increase in the expression of the ompC locus that is independent of the carbon source in the growth medium. We would suggest that the response to acidification of the cytoplasm takes place via the same pathway as osmotic sensing, i.e. control over the activities of the EnvZ kinase and phosphatase activities.

The authors wish to thank the AFRC and Unilever for financial support of this project and in particular we would like to thank Grahame Gould and Martin Cole for their support throughout this work. The authors wish to thank Chris Higgins for the provision of bacterial strains and Charles Dorman for assistance with measurements of DNA supercoiling. The authors wish to thank Dr C. Harwood for his helpful comments on catabolite repression of the porins.

\section{References}

Ahmad, D. \& Newman, E. B. (1988). A deficiency in cyclic AMP results in pH-sensitive growth of Escherichia coli $\mathrm{K}-12$. Journal of Bacteriology 170, 3443-3447. 
AHMED, S. \& BoоTH, I. R. (1981). The effect of $\beta$-galactosides on the protonmotive force and growth of Escherichia coli. Journal of General Microbiology 129, 2521-2529.

Aiba, H., Mizuno, T. \& Mizushima, S. (1989). Transfer of phosphoryl group between two regulatory proteins involved in osmoregulatory expression of the $o m p F$ and $o m p C$ genes in Escherichia coli. Journal of Biological Chemistry 264, 8563-8567.

Booth, I. R. \& Higgins, C. F. (1990). Enteric bacteria and osmotic stress: intracellular potassium glutamate as a secondary signal of osmotic stress? FEMS Microbiology Reviews 75, 239-246.

Brown, M. H. \& Booth, I. R. (1991). Acidulants and low pH. In Food Preservatives, pp. 22-43. Edited by N. J. Russell \& G. W. Gould. Glasgow \& London: Blackie.

CaIRney, J., Booth, I. R. \& Higgins, C. F. (1985). Osmoregulation of gene expression in Salmonella typhimurium proU encodes an osmotically-induced betaine transport system. Journal of Bacteriology 164, 1224-1232.

DE Crombrugghe, B., Busby, S. \& Buc, H. (1984). Activation of transcription by the cyclic AMP receptor protein. In Biological Regulation and Development, pp. 129-167. Edited by R. F. Goldberger \& K. R. Yamamoto. New York: Plenum Press.

Dorman, C. J., Barr, G. C., NiBhriain, N. \& Higgins, C. F. (1988). DNA supercoiling and anaerobic and growth phase regulation of ton $B$ gene expression. Journal of Bacteriology 170, 2816-2826.

Drlica, K., Pruss, G. J., Burger, R. M., Franco, R. J., Hsieh, L.-S. \& BERGER, B. A. (1990). Roles of DNA topoisomerases in bacterial chromosome structure and function. In The Bacterial Chromosome, pp. 195-204. Edited by K. Drlica. Washington, DC: American Society for Microbiology.

Graeme-CoOK, K. A., May, G., Bremer, E. \& Higgins, C. F. (1989). Osmotic regulation of porin expression: a role for DNA supercoiling. Molecular Microbiology 3, 1287-1294.

HEYDE, M. \& PoRTALIER, R. C. (1987). Regulation of outer membrane porin proteins of Escherichia coli by $\mathrm{pH}$. Molecular and General Genetics 208, 511-517.

Heyde, M., lazzaroni, J-C., Magnouloux-Blanc, B. \& Portalier, R. (1988). Regulation of porin gene expression over a wide range of extracellular pH in Escherichia coli K-12: influence of a tolA mutation. FEMS Microbiology Letters 52, 59-66.

Higgins, C. F., Dorman, C. J. \& Ni Bhriain, N. (1990). Environmental influences on DNA supercoiling: a novel mechanism for the regulation of gene expression. In The Bacterial Chromosome, pp. 421-
432. Edited by K. Drlica. Washington, DC: American Society for Microbiology.

Higgins, C. F., Dorman, C. J., Stirling, D. A., Waddell, L., Booth, I. R., MAY, G. \& BREMER, E. (1988). A physiological role for DNA supercoiling in the osmotic regulation of gene expression in $S$. typhimurium and E. coli. Cell 52, 569-584.

HSIEH, L.-S., Burger, R. M. \& DrLiCA, K. (1991). Bacterial DNA supercoiling and [ATP]/[ADP] changes associated with a transition to anaerobic growth. Journal of Molecular Biology 219, 443-450.

Huang, L., Tsui, P. \& Freundlich, M. (1992). Positive and negative control of ompB transcription in Escherichia coli by cyclic AMP and cyclic AMP receptor protein. Journal of Bacteriology 174, 664-670.

MILLER, J. H. (1972). Experiments in Molecular Genetics. Cold Spring Harbor, NY: Cold Spring Harbor Laboratory.

Mizuno, T. \& Mizushima, S. (1990). Signal transduction and gene regulation through the phosphorylation of two regulatory components: the molecular basis for the osmotic regulation of the porin genes. Molecular Microbiology 4, 1077-1082.

Ni Bhriain, N., Dorman, C. J. \& Higgins, C. F. (1989). An overlap between osmotic and anaerobic stress responses: a potential role for DNA supercoiling in the coordinate regulation of gene expression. Molecular Microbiology 3, 933-942.

Prince, W. S. \& Villarejo, M. R. (1990). Osmotic control of proU transcription is mediated through direct action of potassium glutamate on the transcription complex. Journal of Biological Chemistry 265, 17673-17679.

SCOTT, N. W. \& HARwood, C. R. (1980). Studies on the influence of the cyclic AMP system on major outer membrane proteins of Escherichia coli K-12. FEMS Microbiology Letters 9, 95-98.

STock, J. B., Ninfa, A. J. \& STock, A. M. (1989). Protein phosphorylation and regulation of adaptive responses in bacteria. Microbiological Reviews 53, 450-491.

Sutherland, L., Cairney, J., Elmore, M. J., Booth, I. R. \& Higgins, C. F. (1986). Osmotic regulation of transcription: induction of the pro $U$ betaine transport gene is determined by the accumulation of intracellular potassium. Journal of Bacteriology 168, 805-814.

Tokishita, S., Yamada, H., Aiba, H. \& Mizuno, T. (1990). Transmembrane signal transduction and osmoregulation in Escherichia coli. II. The osmotic sensor, EnvZ, located in the isolated cytoplasmic membrane displays its phosphorylation and dephosphorylation abilities as to the activator protein, OmpR. Journal of Biochemistry 108, 488-493. 